Volume 18 Number 1 June 2018.p.185-208

https://doi.org/10.30603/au.v18i1.314

\title{
Berkiprah dengan Kelembagan Politik Tradisional di Kabupaten Barru Sulawesi-Selatan (Studi Sejarah dan Antropologi Politik)
}

\author{
Andi M. Anwar Zaenong \\ IAIN Pare-Pare
}

\begin{abstract}
The origin of tradisional politics in Barru District can be known from the stereotype saying, " Datu ri Tenete, Petta ri Berru, sibawa Mallusetasi, Arung ri Soppeng Riaja , ". It is these three titles of Kings that manifest in the order of colonial politics in sub districs throughout Barru area. In the Dutch colonial era, the government in the area called Onderafdeling. However, after the emergence of Indonesian Republic, the tradisional system was slowly but surely changed by modernization and eventually hard to preserve. Therefore, reactualization is needed to anticipate all changes posed by globalization. Intitution of custom is actually a parameter of self dignity in a nation. Therefore, re-establishing the institution of custom in Barru District is very significant in accordance with the regulation based on 1945 constitution, chapter 32, and also as follow-up of National policy in Regulation No. 10 Year 1993 on the Right of Cultural Preservation. The institution of custom comprises some committees of the heirs of custom order, that is, the descendarts of the King, not those who participated in the colonial politics.
\end{abstract}

\begin{abstract}
Abstrak
Kelembagaan Politik tradisional Kabupaten Barru Sulawesi-Selatan berkiprah secara konfederasional sejak zaman penjajahan berdasarkan falsafah politik lokal," Datu ri Tanete, Petta ri Berru sibawa Mallusetasi, Arung ri Soppeng Riaja"; semuanya terikat di bawah satu Onderafdeling di Sumpang MinangaE. Tetapi setelah Indonesia merdeka, maka sistem politik tradisional yang bersejarah kini terpuruk dari per-kembangan zaman, semua terhapus kebinekaannya setelah gelarnya diganti dengan jabatan camat yang memimpin setiap wilayah. Memelihara sistem politik tradisional berfungsi mengantisipasi setiap perubahan yang menggelobalisasi. Lembaga Adat dalam organisasinya berfungsi mendampingi pemerintah dalam bernegara. Lembaga Adat berkiprah di Kabupaten Barru yang hendak kembali berdiri karena sejarahnya beralasan regulasi sebagai dirujuk berdasarkan UUD 1945 psl 32, juncto UU No 10/1993; pemerintah memajukan Kebudayaan Nasional. Lembaga Adat terstruktur dengan kepengurusan terdiri atas Ketua yang berzilsilah dan beranggotakan di dalam masyarakat, mereka bukannya keluarga kolonialisme di Kabupaten Barru sebagai Leenvorts yang Raja Pinjaman..
\end{abstract}

Kata Kunci: Kabupaten Barru Sulawesi-Selatan, politik identitas, antropologi politik.

Author correspondence

Email: anwar.zenong@gmail.com

Available online at http://journal.iaingorontalo.ac.id/index.php/au/index 


\section{A. Pendahuluan}

Negara Republik Indonesia secara kultural berdiri di atas kumpulan negerinegeri tradisional/Adat, dan secara politik dipetakan sebanyak 19 wilayah ${ }^{1}$. Di antaranya suatu wilayah sebagai Daerah Provinsi Sulawesi-Selatan (termasuk SulBar). Itu berarti di sepanjang wilayah Negara Republik Indonesia menunjukkan, bahwa tiada tempat yang bernaung di bawahnya dapat dibebaskan dari kepemilikan Adat, sehingga bagaimanapun bentuknya yang berkonsolidasi di atasnya, secara kultural hendaknya dipertanggung-jawabkan di setiap area pembangunan dan jangan dibiarkannya berkelanjutan tanpa lebih dahulu berhubungan dengan sosio-kultural dalam mempertahankan dan mengabaikan sistem kepemilikan adat-tradisional. Di sinilah hendaknya dijadikan main stream dan sikap progresif antropolog dalam setiap geliat pembangunan, tetapi apakah semuanya bagi negara telah terakumulasi secara realistis? Jawabannya masih terpundak di atas angin, dan semuanya baru bergerak sebatas cita-cita atau dalam impian belaka.Itulah di antara contoh kebijakan Pemerintah Kota dan Provinsi di Makassar tentang obyek revitalisasi di Lapangan Karebosi sangat menarik dirilis.

Sepanjang terkait misalnya dengan kultural Karebosi yang sekarang dalam permasalahan publik beberapa tahun lalu, terdapat peringatan orang-orang dahulu (H.Zainuddin, Budayawan, tinggal di Pare-Pare, Wawancara, 01 September 2003 ), berkata; 'Engkatu seddi wettu, napole riawani musu'e, maronta'nitu lino', lempe' darani padang'e Karebosi, mauni lebeng dara'e ri Karebosi, narekko' de' naricore' kawali pamoro' sakadoi'i si empa-empa'i. Mompo'nitu seppulo seddi bandera sibawa seddi teddung. Naiyyami nala'e salama' tau makkatenni'e ri wajenpajeng, maccinaung'e ri poncinagori, mattompo'e ri tana maeso'e, poada'i tongengng'e. ${ }^{2}$

Oleh karena itu, di Indonesia dalam menegakkan nasionalisme ke depan, kalau saja berbicara dengan sebuah institusi tradisional misalnya Lembaga Adat,

\footnotetext{
${ }^{1}$ Lihat : Jamali, Abdoel Rauf, Pengantar Hukum Indonesia, (Jakarta: PT. Grafindo Persada, 1999), h. $71-2$.

${ }^{2}$ Artinya: Ada suatu waktu, manakala lawan atau musuh sudah datang dari jurus bawah, maka kehidupan dunia saat itu sudah kacau balau, lapangan Karebosi akan kebanjiran darah. Walaupun Karebosi dalam kebanjiran darah dan pada orang berusaha mengusahakannya kering, dan itu tak dapat dicapai kalau tak dicoret dengan pisau pamoro'(badik yang pernah membunuh) yang bertali temali; oleh sebab itu, muncullah sebelas bendera dengan satu payung. Tak ada orang yang selamat kecuali orang yang berpegang pada sinar subuh hari yang diberi nama wajengpajeng (bhs. Bugis) dan yang bernaung di bawah pohon cinagori (sejenis tumbuh-tumbuhan yang tidak pernah besar), dan orang yang berdiri di depan umum menyatakan kebenaran.
} 
secara antropologis tak dapat dianaktirikan dari pada pembangunan lainnya, misalnya ekonomi, politik dan sebagainya, karena statusnya terkait sebagai mitra pemerintahan republik di bidang kekuatan politik atau kekuasaan. Bahkan itulah sosio-kultural yang sokoguru dan cikal bakal mendampingi Negara Indonesia yang sungguh membangun dan bermartabat. Oleh sebab itu, masyarakat dan tanah air Indonesia saat ini, secara representatif belum dianggap telah meraih kemerdekaannya dari penjajahan.

Terdapat asumsi bahwa sistem pemerintahan sejak kemerdekaan atau republik, tiada lain merupakan sistem perpanjangan kolonial dan lebih akrab diberi sambutan Penjajahan Bangsa Sendiri sebagai disebutkan Sianre Bale Tauwe bahasa Bugisnya; ${ }^{3}$ contoh misalnya penjajahan Pusat atas Daerah, Suku Jawa atas Suku-suku lainnya, keistimewaan Indonesia Barat khususnya Pulau Jawa atas Indonesia Timur, dan secara representatif disebut pula Penjajahan Nasionalisme berkarya. ${ }^{4}$ Bukankah di sela-selanya telah banyak kesempatan yang dipergunakan orang-orang tertentu secara hipokrik di luar tujuan dan ideologi Negara yang sejahtera adil-makmur. Seperti ini dalam rangka penjajahan, disampaikan para penulis Barat yang mengemukakan sebuah tesis dalam pengalaman sejarah umat manusia, bahwa suatu hal yang pasti dalam sejarah umat manusia tentang proses penjajahan atau penaklukan tidaklah dapat dielakkan. ${ }^{5}$

Mereka mencontohkan dari dua belahan, yaitu Timur dan Barat pada awal abad ke 19, merupakan dua bagian dunia dengan tingkat prestise yang berbeda; Barat dengan penuh tenaga hidup dan melangkah di bagian depan kemajuan umat manusia; sedangkan Timur terbenam dalam masa bodoh dan keruntuhannya; itu sudah dapat dibayangkan lebih dahulu, bahwa yang pertama sudah pasti akan menyerang dan menguasai yang kedua 6. Dengan demikian, untuk menagih kerugian sistem politik tradisional sejak kemerdekaan RI, maka kebangkitan Lembaga Adat, khususnya di Kabupaten Barru memiliki pembuktian secara

\footnotetext{
${ }^{3}$ Artinya : orang dimakan oleh sesama orang seperti ikan kecil dimakan oleh ikan besar.

${ }^{4}$ Penjajahan Nasionalisme bagi orang Bugis dahulu berkata; Narekko ri Munri Purana Balanda'E Parentaki Padaidi'si Siparenta-parenta gangkanna Tauwe Sianre' Bale'; artinya, setelah kita dijajah Belanda, pada kita lagi saling memerintah sampai terjadi seperti keadaanya ikan, tradisi ikan berarti orang besar makan orang kecil..

${ }^{5}$ Lihat: Stoddard, L., Dunia Baru Islam, ( Jakarta: Panitia, 1966), h. 88.

${ }^{6}$ Lihat: Ibid. h. 89.
} 
konkrit, empiris dan historikal, sehingga semuanya menunjukkan dapat dengan segera direalisasikan. Oleh sebab itu, substansi politik tradisional dalam kelembagaan adat di sini, sebagai berikutnya dikemukakan pertanyaan; bagaimana berkiprah dengan kelembagaan politik tradisional/lembaga adat Kabupaten Barru Sulawesi-Selatan?

Untuk berkiprah dengan lembaga adat khususnya di Kabupaten Barru, secara bersahaja menarik ditelusuri jejaknya.karena dipersimpangan Kota Barru, dibangun-kan sebuah tugu dan di atasnya terpajang empat buah payung kerajaan secara anggung dan lagi tertutup. Keempat payungnya merupakan lambang daerah, berarti di Kabupaten Barru secara kultural memiliki kebanggaan yang mengalahkan daerah lainnya di Sulawesi-Selatan, Bukankah di atasnya menunjukkan beberapa payung berbeda, itu berarti antara satu payung dan dengan payung lainnya, memahami pluralitas adanya prinsip kehidupan berdampingan, bermasyarakat demi persatuan dan kesatuan, Keempatnya anggung berdiri berarti semuanya tetap tanggung dan tidak mengenal kalah, demikian juga tertutupnya berarti Kabupaten Barru merupakan daerah menarik dipertanyakan, antara lain berarti diberi waktu yang menunggu kapan saja sejarahnya atau lontara (Bahasa Bugis) kembali terbuka. Dengan demikian, secara simbolis sangat menarik diberi makna, sepertinya di atas lambang itu sendiri terdapat keajaiban luar biasa, sebagai disebutkan Ajuara Makerre'E ${ }^{7}$ bahasa Bugisnya.

\section{A. Deskripsi Pokok Pemikiran terhadap Perspektif Budaya Politik}

\section{Tradisional di Kabupaten Barru}

Kabupaten Barru berdiri di atas wilayah tradisional beranekaragam, dan merupakan salah satu pemerintahan daerah di bawah adminstrasi Pemerintah Provinsi Sulawesi-Selatan, atau daerah kebetulan terdiri atas beberapa bekas kerajaan-kerajaan tradisional, atau pada zaman kolonial terdiri atas beberapa swapraja/distrik yang memerintah sebagai kaki-tangan penjajah, semuanya terpadu dipimpin seorang Belanda berpangkat Contorleur atau juga kepadanya disebut Tuan Petoro' dalam bahasa Bugis. Itulah secara terstruktur berada di

\footnotetext{
${ }^{7}$ Artinya: Pohon beringin yang angker.
} 
Berkiprah dengan Kelembagan Politik Tradisional di Kabupaten Barru SulawesiSelatan (Studi Sejarah dan Antropologi Politik)

bawah salah satu wilayah adminisratif bernama Onderafdeling di Sumpang Minanga'E (sekarang wilayah yang artinya sederajat dengan kecamatan), atau secara administratif kedudukannya di bawah sistem pemerintahan di Pare-Pare yang lebih tinggi disebut Afdeling (wilayah sekarang ini sama artinya dengan Kabupaten/Kota), dan Pejabatnya seorang Belanda diberi pangkat AsistentGouverneur di daerah bergelar Gezaghebber ${ }^{8}$.

Tentu saja sebagai akar berdirinnya strategi pemerintahan kolonial di Kabupaten Barru, dari kebijakannya tetap saja mengambil contoh beberapa istilah sebagai bentuk kearifan lokal yang berasal dari sistem pemerintahan tradisional, kecuali setelah semuanya di bawah kemerdekaan yang berpola Pembangunan Nasional Republik Indonesia, sehingga dari padanya terpaksa berubah secara modern yang ala Barat bergandengan dengan misi Jawanisasi, Demikian selainnya berdasar-kan kebijakan lebih jauh secara sentralistik tidak lagi menghiraukan masyarakat tradisional setempat sebagai dalam UU No. 5 Tahun 1967 Tentang Pemerintahan Daerah dan Desa.

Bukankah hal di atas berkembang, karena berangkat dari kebijakan kolonial yang telah melenceng atau menyimpang, dan kini secara natural terhadap nama atau sebutannya belum saja kembali dilestarikan, di mana sebagai budaya pada setiap istilah pemilik kekuasaan, misalnya sistem politik tradisional di SulawesiSelatan sebagai disebutkan Ade' bahasa Bugis; sehingga istilah Wanua, Limpo', Kampong atau Lembang diganti dengan istilah Dusun, Desa, Lingkungan, Lurah, dan Kecamatan; seterusnya kepada istilah Bupati dan Kabupaten.

Istilah gelar tradisional di setiap tempat yang tersebar misalnya Datu.Petta, Sulle-datu;Arung, Anreguru,Sulle-watang, Matowa, Gellareng dan Jennang, ${ }^{9}$ yang terstruktural dibagi sebagai masing-masing memimpin wilayah, semuanya beransur diganti dengan istilah berbau pembangunan Indonesia disebut Kepala atau Ketua. Sehingga istilah di setiap wilayah telah tersebar luas meninggalkan

\footnotetext{
${ }^{8}$ Lihat: Mattulada, Latoa, Suatu Analisis Terhadap Antropologi Politik Orang Bugis, (Ujungpandang: Hasanuddin University Press), h. 462.

9 Artinya: "Datu" adalah Raja/Kepala Negara, "Petta" adalah Raja daerah setingkat Gubernur. "Sulle' Datu" adalah Pengganti Raja di daerah yang berstatus negeri dilindungi, "Anreguru"adalah Panglima Kerajaan yang memimpin prajurit berperang dan bekerja, "Sulle'watang" berfungsi sama dengan Jenderal yang mendampingi Raja di bidang militer. "Matowa " adalah kepala distrik yang menjalankan pemerintahan umum, "Gellareng dan Jennang " juga adalah keduanya aparat kerajaan yang memimpin rakyat yang letaknya di pegunungan atau di pantai.
} 
budaya lokal dari tingkat kabupaten, kecamatan sampai desa atau lurah, dusun dan lingkungan. Atau sebutan istilah tradisional yang dikenal sebelumnya telah diganti dengan istilah di luar sistem tak dipergunakan sebelumnya di masing-masing wilayah.

Bentuk kekuasaan adat/tradisional dengan berbagai struktural dan federalnya disebut Kerajaan ( eksistensinya sekarang ini merupakan unsur budaya, dan relevansi-nya disebutkan Lembaga Adat ) Di Kabupaten Barru terdiri atas 5 bekas Kerajaan, yaitu Tanete, Barru, Balusu dan Kiru -Kiru Soppeng Riaja, serta Nepo Mallusetasi. Namun, untuk eksistensinya dahulu sejak zaman kolonial, sinerginya tetap saja diperlukan untuk terjalinnya kesatuan lokal, sehingga semuanya tergambar di dalam sistem konfederasional politik tradisional; " Datu ri Tanete, Petta ri Berru Sibawa Mallusetasi,Arung ri Soppeng Riaja“. 10

Itulah sebagai di atas, di Sulawesi-Selatan tercatat di antara Swapraja Asli11 yang kedudukannya sederajat dengan Swapraja-Swapraja lain; misalnya Bone, Luwu, Gowa, Soppeng, Wajo dan sebagainya. Dengan demikian, perspektif sebagai digambarkan untuk membangun Lembaga Adat di Kabupaten Barru, telah diagendakan Pemerintah Daerah atau Bupati sebagai sebuah pekerjaan rumah, sehingga dari padanya diupayakan dengan langkah-langkah tak sederhana, Yakni hendaknya berdasarkan langkah, terlebih dahulu dibijaki dengan fasilitas pelurusan sejarah di atas beberapa titik wilayah tradisional, dan kembali mengekspresikannya sejauh arti dari pada maksud kebudayaan.

Dengan demikian, Pemerintah berdasarkan arah pembangunan Indonesia dalam UUD '45 dan GBHN, memandang kebudayaan dari dua sudut pendekatan; yaitu pendekatan sektoral dan pendekatan regional. Secara sektoral, apa yang dimaksud dengan kebudayaan dalam pasal 32 tidaklah mengacu kepada kultural, tetapi saja mengacu kepada hal-ihwal kebudayaan. Hal ini akan kelihatan pengertiannya, apabila kita melihat kepada struktural yang mengelola “ Kebudayaan " di Departemen. Oleh karena itu, menurut Marzali 12 bahwa

\footnotetext{
${ }^{10}$ Artinya :Datu istilah prestise Raja di Tanete, Petta istilah prestise Raja di Barru dan Mallusetasi, Arung istilah prestise Raja di Soppeng Riaja.

${ }^{11}$ Lihat: Mattulada, Op. Cit. h. 355.

12 Lihat : Amri Marzali, Antropologi \& Pembangunan Indonesia, (Jakarta: Kencana Indonesia, 2007), h. 49 .
} 
terjemahan dari Direktorat Jenderal Kebudayaan dalam bahasa Inggeris The Directorate General of Culture Affairs, bukan The Directorate General of Culture.

Dalam GBHN (khususnya 1993), sektor kebudayaan digabungkan dengan sektor kesejahteraan rakyat dan pendidikan. Kemudian dengannya yang lebih rinci, sektor kebudayaan dipecah ke dalam sub-sub sektor yang lebih kecil. Terhadap isi dari sektor kebudayaan tersebut, adalah sebagai berikut:

1. Kepercayaan terhadap Tuhan Yang Maha Esa

2. Nilai Budaya Indonesia

3. Tanggung Jawab Sosial dan Disiplin Nasional

4. Pembauran Bangsa

5. Bahasa dan Sastra

6. Kesenian

7. Perbukuan dan Kepustakaan

8. Warisan Budaya dalam bentuk Artepak, Lokasi, Bangunan dan Tulisan Kuno $^{13}$

Tentu saja berdasarkan beberapa sub kebudayaan di atas, terutama kaitannya dengan substansi Lembaga Adat, yakni tergambar dalam nilai budaya (sub 2), dan warisan budaya dengan berbagai bentuknya (sub 8).

Secara regional, Lembaga Adat sesungguhnya telah mapan dengan berbagai peninggalan sejarah, sehingga untuk pembentukannya di setiap tempat akan diproses secara natural dari bekas pemerintahan tradisional yang terbentuk lebih dahulu dari pada kekuatan ideologi kolonialisme. Lembaga Adat sebagai tak ayal substansinya, di dalamnya menunjukkan hal-hal tentang keaslian jati diri setiap daerah, itulah dari padanya dijadikan parameter yang seharusnya berfungsi sebagai mitra pemerintahan republik, khususnya untuk bermitraan mengenai pembangunan negara (development) atau modernisasi. Tetapi, kini dengannya secara realitas di sepanjang jauh telah ditinggalkan dan terasa belum terhingga diberi kesempatan kembali dibahas secara tuntas, bahkan di sisi lain terdapat personal yang di antaranya hendak berbicara lain, sebagai disebutkan kelompok

\footnotetext{
13 Lihat: Ibid., h. 50
} 
orang-orang Mbalelo', untuk bagaimana bertahan membela status quo peninggalan kolonial, khususnya di Dua Kecamatan; Soppeng Riaja dan Tanete.

Itulah terhadap adat-tradisional atau Lembaga Adat di Kabupaten Barru terus saja mengambang kipranya sebagai disebutkan Makkamporoi bahasa Bugisnya, walaupun sumber sesungguhnya telah banyak didukung secara historis, antropologis, dan arkeologis, sehingga Kabupaten Barru di Sulawesi-Selatan di bidang kebudayaan sesungguhnya merupakan daerah terpuruk dan tertinggal dari daerah lain, oleh karena lebih banyak tertutup di bawah peranan dan pengaruh sistem politik kolonial disebut Rapang/Leenvorts, tidakkah sekarang saja sebagai peninggalan kolonial di antaranya masih mengisi struktural yang mengatur sistem pemerintahan Daerah dan Desa (UU No. 05 Tahun 1967). Oleh karena itu, demi untuk membangun bangsa bermartabat yang mestinya kembali kepada tradisional kerajaan-kerajaan, diperlukan langkah-langkah dan pendekatan, baik melalui kebijakan pemerintah maupun dengan keilmuan akademik yang menggagaskan nilai kredibilitas hasil-hasil penelitian.

\section{B. Advokasi Penegakan Lembaga Adat Se Wilayah Kabupaten Barru}

Seperti apa dan caranya bagaimana membangun Lembaga Adat di Kabupaten Barru atau How get and reform "Lembaga Adat " at Kabupaten Barru ? Lembaga Adat menurut Budayawan Prof. Dr. H. Abu Hamid berkata; Lembaga Adat adalah organisasi sosial, baik yang disengaja terbentuk maupun yang tumbuh secara wajar dan berkembang di dalam sejarah kebudayaan masyarakat hukum adat. Lembaga ini menurut Asma Saing 14 berwenang untuk mengatur, mengurus dan menyelesaikan berbagai masalah kehidupan yang berkaitan dengan adat istiadat atau hukum-hukum adat di lingkungannya.

Deskripsi adat atau sistem politik tradisional sebagai diartikan salah satu unsur budaya bukanlah sebuah persoalan baru di tingkat negara secara nasional, tetapi itu telah dipresentasekan sejak awal kemerdekaan. Disinilah halnya dalam UUD 1945 pasal 32, di dalamnya menegaskan;"Pemerintah Memajukan Kebudayaan Nasional Indonesia." Tetapi, kaitannya sejak kemerdekaan 45, pengertian tentang kebudayaan belum memberikan kesegaran fokus dan

${ }^{14}$ Asma Saing: “ Kebijakan Pembentukan Lembaga Adat/Pemangku Adat “, Makalah (2007), h. 04. 
ketajaman operasional, terutama ketajaman budaya bernuansa kerajaan atau kraton, dan substansinya di masyarakat sudah terselubung bahkan terkubur, atau di mana saja kalau bukan dikatakan sengaja dikaburkan. Bukankah sebabnya di antara Pemuka/Tokoh/Sesepuh/ Cendikiawan Bangsa ini ada saja pemikirannya, bahwa semuanya itu merupakan tantangan yang berpotensi mengancam keutuhan ideologi NKRI yang berbasis negara bangsa, bahkan potensinya kalau perlu bagaimana kemungkinannya dapat dijauhkan, atau itu dipandang merugikan kultural politik yang mayoritas di hadapan publik warga negara ke depan, dan dengan alih-alih menggunakan prinsip positivisme, bahwa dahulu memang lain dan sekarang juga lagi lain, dan hal itu dalam bahasa Bugis disebutkan Esso'E Essota' Tosi artinya hari ini memang kesempatan kita berkuasa, adapun besoknya atau lusa tidak diketahui bagaimana kewenangan kita.

Bukankah biasanya terdengar isu dalam misi Proklamator Bung Karno, secara terencana di Pulau Jawa dan Penduduknya terlebih dahulu dibangun sebagai daerah-daerah industri, dan SDM-nya telah lebih maju, setelah di seluruh nusantara dikuasai dalam waktu seratus tahun lamanya, dan terbukti bertambahnya misi kekejaman nasionalisme selama 32 tahun bahkan bertambah sesudahnya setelah di tangan orang kuat berbadan militer dan dianggapnya Rezim SoehartoPlus SBY- nya. Itulah di sini barangkali bukan kebetulan, kalau semuanya tersimpul diberi sebutan saja sistem Neo-Penjajah-Penjajah di Indonesia.

Oleh sebab itu, barangkali menarik dipertanyakan bakal apa kemungkinan terjadi, kalau bukan zaman berikutnya ditunggu menghadapi gerakan reformasi Jilid II. Yakni dengan zaman berdasarkan idion-idion yang menegakkan misi budaya; menurut adat dan agama di seluruh pelosok tanah air secara bervariasi, sehingga antara keduanya berjalan secara resepsional dan sinkronis sebagaimana pepatah Melayu berkata, Adat bersendi Sara', sebaliknya Sara' bersendi Adat. Dalam falsafah Bugis Tradisional sebagai dirangkaikan antara keduanya, menarik dikemukakan suatu ideologi antara keduanya, menunjukkan tak dapat dipisahkan;15 “ Mappakaraja'I Sara'E ri Ade'E, Mappakalebbi'I Ade'E ri Sara'E “. 16

15 ......., (Proyek Naskah UNHAS, t,th.), h. 155.

${ }^{16}$ Artinya: Adat memuliakan Sara' dan Sara' mengagungkan Adat. 
Tentu saja seperti apa hasilnya misi Penegakan Syari'at Islam sebagai telah berkomandan di semenanjung jazirah Republik Indonesia bakda kejatuhan Rezim Orde Baru, kalau bukan secara bersama harus bersinergi dengan penegakan adat/ tradisional. Di Sulawesi-Selatan adalah penegakan misi tradisional Panngadereng, di dalamnya telah tercakup Penegakan Syari'at Islam sebagai disebutkan Sara' bahasa Bugisnya sesudah Ade', Bicara, Wari', dan Rapang. 17 Dengan demikian, maka sistem kesejarahan berikutnya bukan mustahil tidak berulang dengan menyusulnya Post Modernisme atau Post Positivisme, yakni suatu zaman diberi makna anti modernisasi, dan secara loyalitas di dalamnya mengajak masyarakat kembali ber-kiprah kepada zaman spiritualisme, sebagai disebutkan Makkeade'E bahasa Bugisnya.Yakni kembali bersemangatkan dengan sistem tradisional menurut adat dan agama atau kepercayaan.

Apakah sekarang tidak menarik dipertanyakan, mengajukan teka-teki, mengapa di Indonesia sebagai Kepala Negara atau Presiden belum pernah sekali terpilih dipimpin seseorang Pemangku Budaya alias Pemilik Kraton, sementara selainnya dengan berbagai profesi, bergantian sepertinya sistem perbengkelan bongkar pasang, Demikian ke bawah di daerah-daerah misalnya Kabupaten Barru, juga sebagai Bupati belum pernah sekali seseorang pemilik tradisional/adat, kecuali dipimpin keluarga sebagai disebutkan Leenvorts bahasa Belanda artinya keturunan Raja Pinjaman/To Masaleppang 18 bahasa Bugis. sehingga dalam hubungan ini dan relevansinya ber-dasarkan tradisional orang dahulu, mereka dalam pesan-pesannya antara lain berkata;" Iyatu tongeng'e memeng Datu yarega Arung To RiengkalingaE Adanna, rewe'muatu parimeng natettong'na Ade'e', rilegga'toni mangke'e yarega rapang'e, engka'e tania'e riyaseng ammemengeng."19

Dengan demikian, berbicara demi kebenaran sejarah tradisional perlu ditegaskan, bahwa sekarang terdapat dua sistem kubu penjajahan sedang bergejolak; yaitu Pengaruh Barat-Eropa (modernisasi dan globalisasi) dan Pengaruh Mayoritas Tradisional/Jawanisasi. Oleh sebab itu, maka setiap gerakan di daerah selama ini dituduh sparatisme, seakan langsung dinyatakan telah

\footnotetext{
17 Lihat: Mattulada, Op. Cit. h. 444.

${ }^{18}$ Artinya: Penyandang pangkat atau Penjabat

${ }^{19}$ Artinya: Yang dinamakan kebenaran yaitu Ade' (Bugis) yang dimaksud Datu dan Arung, akan kembali memerintah, tegaklah Adat dan dibubarkan yang Boneka karena itu bukan kebenaran.
} 
menagih kemerdekaan di daerahnya, walaupun politiknya secara tersendiri kemungkinan ada kebenaran-nya.Itulah salah satu alternatif beralasan dibuatkan suatu instrumen untuk membangun lembaga Adat, sekarang ini kebijakannya telah diatur pemerintah dalam UU No. 5 Th 1992 Yo.PP No. 10 Th 1993 Tentang Hak Perlindungan Cagar Budaya.

Menurut penulis, kebijakan itu merupakan middle street dan gerakannya dianggap bersemikan terbentuknya otonomi berkualitas di daerah, tetapi jangan hendaknya hal ini diwaspadai sebagai suatu kekhawatiran dalam berintegritas kebangsaan NKRI. Dengan demikian, di sinilah perlunya pemikiran untuk kembali menekankan bagaimana sesungguhnya sistem kebinekaan menurut Pancasila dan UUD 1945, juga sebaliknya; hendaklah jangan pula prinsip kesamaan dan kesatuan di pelosok tanah air dipahami bersifat mutlak tanpa batas.Tentu di sinilah letaknya wibawa Lembaga Adat sangat berperanan dan berjaga-jaga menghadapi ancaman di Indonesia di era globalisasi. Dengan demikian, di sisi lain berdasarkan legitimasi ilmu pengetahuan atau sains, maka hal ini merupakan tugas ilmuwan antropologi untuk menjembatanginya di antara kedua fakta, yakni dengan melihat dampaknya kemerosotan akhlak/moral di seluruh pelosok tanah air, disebabkan pengaruhnya materialisme di setiap saat, korupsi merajalela di setiap lini, konsumerisme, hedonistik, hipokrik, individualistik, dan sebagainya.

Oleh sebab itu, penulis salah seorang putra daerah lahir di Mangkoso, Selasa 19 April 1957, dari jauh dan sejak lama berupaya menghadapi kemungkinan sejarah diperkirakan kembali berulang, setelah diprediksikan satu abad sejak kejatuhannya kerajaan-kerajaan di Sulawesi-Selatan ke tangan Belanda tahun 1906. Tentu saja berdasarkan sejarah setelah terhingga sampai tahun 2006 dan seterusnya, demi fenomennya telah ditandai sebagai disebutkan para ilmuwan; di dalam waktu seratus tahun akan terjadi perubahan hidup umat manusia. Juga sejalan dengan doktrinal Islam sebagai diajarkan Muhammad Rasulullah saw bahwa dalam waktu seratus tahun akan lahir pemikir sebagai bakal Mujaddid atau Pembaharu, sehingga baginya merupakan seorang Reformator ${ }^{20}$, atau sehubungan halnya dengan pandangan sejarah berikutnya, tidaklah dapat disebut-sebut suatu

${ }^{20}$ Lihat: A.J. Wensinck, Concodance Et Indices De La Tradision Muslimane, (Leiden E.J Brill, 1936), h.324. 
sejarah kalau tidak dikembali-kan berulang. ${ }^{21}$ Jadi dengannya apa dan bagaimana berdasarkan teori tersebut, tentu saja kelak pada zamannya dan merupakan bom waktu, bahwa apa saja kiranya dibangunkan Kabupaten Barru dibalik sistem pengulangan sejarah. Bukankah waktu senantiasa bergiliran di antara manusia, dan itu merupakan prinsip dalam Islam yang secara linear diperingatkan Allah swt. 22

Dalam bahasa Bugis sebagai falsafah sejarah berkata; Narekko' narapi'ni kajajian mappurallalo'e, sipangumuruken tauni ettana, majeppu rewe'ni wettu'e makkatenni ripammulanna."(H.M.Arafah Dg Leppe, Pensiunan Veteran RI, tinggal di Polewali-Mangkoso, Wawancara) Oleh sebab itu, jika persentuhan antara institusi pemerintahan dan kelembagaan politik tradisional se Kabupaten Barru di kemudian hari, maka faktanya itu merupakan indikator sejarah yang menyambut Negara Indonesia berubah.

Tentu saja berdasarkan prediksial tersebut, sebelumnya secara kultural telah terliput ideologinya, seperti kebanyakan futurolog berasal dari dua Kerajaan berkata: 'Aja' muengka salaiwi Tanete, narekko' engkani titti' onroiwi titti'na, narekko' engkani moppang, onroiwi alekke'na”.23“ Iyatu Tanete engka punnana', matu' seuwwa wettu' engka'i passapa'na, ri sappa'i ri wijalawona."24" Aja' muengka salaiwi Kiru-Kiru, narekko' engkani titti', onroiwi titti'na, narekko' engkani moppang,onroiwi alekke'na". 25 "Aja' muengka salaiwi Kiru-Kiru, nasaba' matu engkatu wettu, mompo'i wijalawona “26

Ideologi sebagai telah digambarkan, juga dari Dua Kerajaan lainnya; Barru dan Bone berkata 27;" Minasa mabbulo sibatang, mallebu tello' palewai tana Asalamareng'e Beru, niga tengkang balempang nagaru wara', iyatona nama-

\footnotetext{
${ }^{21}$ Lihat: Sunarmi, Sejarah Hukum, (Rawamangun Jakarta: Kencana Prenada Media Group, 2016) Cet. I, h. 7. Dan Lihat: M. Dien Majid \& Johan Wahyudi, Ilmu Sejarah Sebuah Pengantar, (Jakarta: Kencana Prenada Media Group, 2016). Cet. I. h. 173.

22 Lihat: Q.S., 03: 140

${ }^{23}$ Artinya: Janganlah kamu tinggalkan Tanete, jika keadaannya telah miring, tinggallah pada bagian pemiringannya, dan jika telah bertelungkup-tiarap, tinggallah pada punggungnya.

${ }^{24}$ Artinya: Bumi Tanete ada pemiliknya, sebentar suatu saat dicari oleh ahliwaris ketrunannya bergelar Wijalawo.

25 Artinya: Janganlah kamu tinggalkan Kiru-kiru, jika keadaannya telah miring, silahkan tinggal dipemiringannya, dan jika telah bertelungkup-tiarap, tinggallah pada bagian punggungnya.

${ }^{26}$ Artinya: Janganlah kamu tinggalkan Kiru-kiru, sebab sebentar pada suatu waktu akan muncul keturunannya bergelar keturunan labu (Wijalawo)
} 
Berkiprah dengan Kelembagan Politik Tradisional di Kabupaten Barru SulawesiSelatan (Studi Sejarah dan Antropologi Politik)

ngureng; Nigi-nigi tetta' salima' tetta' pabbingeng, iyatona natongkang ware'; narekko' titti' wanua'e Beru narionro'i titti'na, narekko' moppang'i, narionro'i oppang'na. “ 28 Aja' Muengka Salaiwi Bone Narekko Engkani Titti Onroiwi Benrengna, Narekko' Engkani Moppang Onroi Alekke'na." 29

Oleh sebab itu, di Kabupaten Barru di bawah salah satu perubahan dengan terbentuknya Lembaga Adat, konsepsinya merupakan awal perombakan bersifat menyeluruh di semua tempat. Demikian untuk perubahannya adalah tidak semena-mena dihadapi, kecuali dibutuhkan secara berproses, dan mengenai tehnis perubahan-nya dikemukakan salah seorang Peneliti dalam Seputar Indonesia, bahwa proses perubahan suatu zaman tidaklah berjalan linear atau bersifat alami. Tetapi terpenting di dalamnya, dibutuhkan pula seseorang secara ksatria untuk merubah situasi dengan jalan menebarkan pemikiran-pemikirannya. ${ }^{30}$ Demikian selama ini dalam sasaran pemikirannya beransur dilakukan penulis, terutama disebarkan melalui dukungan bidang penguasaan ilmu pengetahuan/penelitian atau berdasarkan kemajuan sains dan teknologi yang kini dianggap unsur paling dominan, demi menuju tercapainya kesepakatan atau konsensus ${ }^{31}$

Penulis berpendapat, dalam rangka berdirinya Lembaga Adat Kabupaten Barru diperlukan langkah-langkah; selain faktor kebijakan pemerintah menurut undang-undang, juga beberapa hal secara akademik hendaknya dilakukan, yaitu melalui penelitian lebih dahulu mengenai kesejarahan di beberapa tempat, terutama di wilayah bekas Swapraja Tanete dan Soppeng Riaja, menyusul kesejarahan di wilayah Swapraja Mallusetasi-bekas Kerajaan Nepo. Tentu saja kejadiannya itu di antara manusia kembali kepada kekuasaan Allah swt, atau secara linear misinya dijalankan sesuai beredarnya siang dan malam, meskipun kini persoalannya bagi penulis telah beransuran dilakukan sejak tahun 2003,

\footnotetext{
${ }^{28}$ Lihat: Abdul Rahim, Op. Cit. h. 52/ Artinya: Harapan yang bersebatang bambu dan bundar telur bagi orang yang menormalkan kembali bumi keselamatan tanah Berru (Barru)................. jikalau tanah Barru miring ditempati pemiringannya, jika keadaannya tiarap, maka ditempati tiarapanya.

${ }^{29}$ Artinya: Jangan kamu tinggalkan Bone jika keadaannya telah miring tempati sampingannya, dan jika keadaannya telah tiarap duduklah dipunggungnnya.

${ }^{30}$ Muhibbin AM, Staf Peneliti FKIY Yogyakarta, " Seputar Indonesia “ Berita Harian ", Resensi Buku, Menyelami Pemikiran Tokoh dalam resensi buku Marnie Hughes-Warrinton " 50 Tokoh Penting Dalam Sejarah ", terbit Minggu, 6 April 2008..

${ }^{31}$ Lihat: Ahmad Fedyani Saifuddin, Antropologi Kontemporer, Suatu Pengantar Kritis Paradigma, (Rawamangun Jakarta: Kencana Prenada Media Group, 2006), h. 358.
} 
misalnya dalam berbagai topik aktual; (1) Sistem Politik Tradisional di Soppeng Riaja Bekas Kerajaan Lili' Kiru-Kiru dan Balusu Kabupaten Barru; (2) Sejenak Melirik Institusi Swapraja Soppeng Riaja Kabupaten Barru Sulawesi-Selatan; (3) Coppo' Lalabata Tanete, Perspektif Bumi Hak Milik Tradisional Kerajaan Tompo Bulu Matajang Kabupaten Barru, (4) Mangkoso Kota Santri Perspektif Bumi Hak Milik Tradisional Kerajaan Laboso Soppeng Riaja Kabupaten Barru, (5) Barru Berpotensi Dimekarkan dengan Pembentukan Kabupaten Nepo, (6) Sistem Politik Tradisional, Sejarah Institusi dan Lembaga Politik Kabupaten Barru, (7) Barru Beralasan dengan Nama Reformasi Kabupaten Tanete Barru, dan sebagainya;

Tentu saja menurut hasil-hasil penelitian di atas, untuk sementara sinopsisnya tersimpul; bahwa Sistem Politik Tradisional se Wilayah Kabupaten Barru adalah bukan kekuasaan milik siapa-siapa, tetapi milik seseorang keluarga tradisional Ade' Mappuraonro'E sifatnya asli-pribumi atau istilah ToTellengkang/To Punnana Tana-wanua bahasa Bugisnya, dan bukan sebaliknya keluarga sebagai saja Ade' Maraja sifatnya To Saliweng/To Matama-tama bahasa Bugis artinya pendatang atau non pribumi. Ia kebetulan di Soppeng Riaja muncul bersahaja di antara manusia lainnya dalam se-keluarga, se-kampung, se- wilayah Daerah Kabupaten/ Provinsi, dan se-tanah air Indonesia, Ia saja sejak lahir berdemosili tetap di atas bumi pemangkuannya Mangkoso Kota Santri bergelar Bumi La Tenri Bali Arung Laboso. Sistem kekerabatannya di Kabupaten Barru tersimpul sebagai seseorang Wija Matola Ade'Mabbulo Sibatang' Mallebu Tello', Mattulu' Tellu'i Temmalara, sehingga manusianya dianggap pribadi seseorang To Mompo' Ri-ale' Ri-aseng'e Wija Lawo ${ }^{32}$ bahasa Bugisnya, setelah ia sendiri sekeluarga dan sekerabat hidup ter-selubung/Takkasubbu lebih seratus tahun lamanya.

Secara akademik, sebagian penelitiannya telah dipublikasikan di beberapa Jurnal Ilmiyah Perguruan Tinggi, Berita Harian dan Majallah 33, Baginya seorang pribadi bersifat ksatria bekerja sepertinya seseorang Messianis atau Mujaddid dan Al-Mahdi. Demikian itu sepanjang dilaksanakan, maunya tidak pernah dipaksakan

\footnotetext{
${ }^{32}$ Artinya: Orangnya dibangkitkan seperti keadaannya seorang Messianis di Masyarakat.

${ }^{33}$ Wijalawo adalah istilah simbolis secara harfiyah dalam bahasa Bugis diterjemahkan keturunan labu, tetapi arti secara makna adalah keturunan dari para raja yang kembali bangkit ke posisi semula setelah tersimpan dalam waktu menelan se abad.
} 
Berkiprah dengan Kelembagan Politik Tradisional di Kabupaten Barru SulawesiSelatan (Studi Sejarah dan Antropologi Politik)

bergerak secara reaksioner, apalagi bertingkah keterbukaan secara revolusioner, melainkan baginya memiliki semangat keuletan dan ketabahan Temmanginngi' Kasiasi, Mamminasa ri Pammase Marajana Dewata Seuwa'E, bersabar menunggu situasi dan perkembangan bagaimana kehendak dan takdir Allah swt, juga baginya bersetia-kawanan menerima reaksi, biasanya dituduh subversi, dan bermacammacam kebencian orang-orang lain, ada berkata gossip, fitnah, gunjingan, atau sekali-sekali dimaki dan diancam seketika, dan itulah semuanya disikapi secara linear/alami dan evolusioner.

Dalam hal demikian, baginya menerima apa adanya, disamping berisengiseng menelusuri tujuan untuk diadakannya reformasi total masyarakat Kabupaten Barru. Demikianlah menurutnya, bahwa untuk meraihnya jangan hendaknya bersifat instan, kecuali tetap mengingat pesan-pesan atau Pau-Pau To Riolo berisiLempu',Acca, Getteng-Bette', dan Assitinajang, berkata; 'Aja' mu'angoa'i onrong, aja' to muma-cinna'i tanre tudangeng nasaba' de'tu mulle'i padecengi tana yarega kampong'; risappa'po mu'ompo', rejello' po mu'akkengau "34 atau 35“ Aja' Muma-nginngi' kasiasi, agangka uleanngi Malempu'E, nasaba iyatu Lempu'E Mauni Telleng Mompo' Mua “.Naiyya Lempu'e Riyala Modala' Alampereng Sunge' Pamale'na “ Ritoro'i Lempu'E ri Ceko'E-Jekko'E, Naiyakiya MappatentuE Lempu'e Мua “. Narekko' Mateki rilalenna Lempu'e, Engkaki Mate Risantangi “. 36

Pada tahun 2007 di Ruang Pola Colliq Fuji'E Kantor Bupati Kepala Daerah Kabupaten Barru, telah diadakan lokakarya tentang sosialisasi pembentukan Lembaga Adat dan dihadiri Budayawan Sulawesi-Selatan Prof. Dr. H. Abu Hamid, tetapi sampai saat ini telah saja menyisakan suatu pertanyaan, bahwa mengapa dan bagaimana berdasarkan masalah tersebut, kini belum sampai diperdakan sebagai kebijakan Pemerintah Daerah, sementara sosialisasinya telah berlangsung

\footnotetext{
${ }^{34}$ Artinya; Jangan serakahi kedudukan, jangan pula terlalu menginginkan kedudukan tinggi, kalau begitu kamu tidak mampu memperbaiki negeri atau kampung, nanti kamu dicari baru muncul, nanti ditunjuk baru kamu mengia.

35Lihat: A. Rahman Rahim, Nilai-Nilai Utama Orang Bugis, (Ujungpandang: Lembaga Penerbitan UNHAS, 1985). h. 160.

36 Artinya ; Jangan dijenuhkan kemiskinan, tetaplah dalam kebenaran atau kejujuran, sebab kejujuran biarpun tenggelam muncul juga; Jika kejujuran dijadikan modal sesunggunya ia dipanjangkan umurnya oleh Tuhan; Jika orang meninggal karena dalam kebenaran atau kejujuran, sesungguhnya ia meninggal diberi santan kelapa; Dikalah kejujuran oleh penghiyanat, tetapi yang menentukan kebenaran jua
} 
lama 10 tahun. Terdapat hipotesis kerja sebagai perkiraan faktor-faktor, antara lain;

Bahwa di Kabupaten Barru dimaklumi daerah terbanyak macamnya jenis kekuasaan politik diusung kategori peninggalan kolonial, misalnya saja status pranata politik sebagai pengganti tradisional berasal dari bekas Kerajaan Soppeng bergelar Arung Pancana dan Arung Lalolang sebagai keduanya diberi saja fungsi mediator di wilayah bekas Kerajaan Tanete,tradisionalisasi pengganti caretaker di wilayah bergelar Petta Ade' Lipukasi di atas wilayah bekas Kerajaan Barru sebagai hal dalam masyarakat dikenal dalam bahasa Bugis Tana Wassele' Rumpa' atau Butta Beta Musu'na Kerajaan Tanete, yakni sebagai wilayah sebelumnya terkenal berasal dari kekuasaan raja memerintahBata Ritoja ArungBerru (1895-1906). Beliau ini sepeninggalnya raja bergelar anumerta Petta Matinro'e ri Gowa. ${ }^{37}$

Demikian status politik kolonial bergelar Arung Soppeng Riaja di Wiringtasi, Lawallu dan Mangkoso sebagai diberi istilah tradisional Rapang bahasa Bugisnya, yakni dari artinya saja menunjukkan Boneka Kerajaan di atas beberapa wilayah bekas pemerintahan tradisional/adatgemenschap, yaitu Balusu, Kiru-Kiru, LabosoSiddo, Batu-Pute, Ajakkang dan sebagainya; Arung Mallusetasi di Pare-Pare merupakan sekutu diberi kekuasaan politik kolonial di wilayah bekas Kerajaan Nepo. Bukankah sebagai kebenaran di Mallusetasi berdasarkan prestise Adat/Tradisional, hendaknya berasal dari garis tradisional Raja Nepo I Sima Tana bergelarPetta Tellu Latte'e. Tentu pula jangan terlupakan dengan para pelaksana pemerintahannya bergelar tradisional Ade'Patappulo'e. Sehingga untuk berbicara secara tuntas dan tidak terkeping-keping diperlukan waktu dan sponsor untuk diseminarkan.

Sehubungan dengan hal di atas, terdapat komentar Raja diibaratkan batu besar sedangkan orang banyak atau rakyat umumnya dikiaskan pasir atau batu kecil, dalam komentarnya berkata;" Tallemme'i batu'e (Datu'e yarega Arung'e), menre'i kessi'e (To maega'e); matu seuwani wettu, wekkasisemmi kedo batu'e, lao riyawani parimeng kessi'e, makkutoniro ebara'na, narekko mompo'ni parimeng

\footnotetext{
37 Lihat: Abdul Rahim,, Sistem Pemerintahan Tradisional Bekas Kerajaan Barru, (Tesis PPs Unicerstas Hasanuddin, 2005), h. 105.
} 
Berkiprah dengan Kelembagan Politik Tradisional di Kabupaten Barru SulawesiSelatan (Studi Sejarah dan Antropologi Politik)

Datu'e yarega Arung'e ( A. BatuEja, tinggal di Tompo' Penna', Tanete, Wawancara). ${ }^{38}$

Demikianlah dari beberapa-hal di atas, secara formal merupakan sumbersember sejarah pembentukan Lembaga Adat sebagai kelak diakses antara lain di Kabupaten Barru, dan jangan hendaknya dibicarakan terpenggal-bercerai-berai, melainkan terfokus dibahas dan terpadu, sebaiknya berangkat dari satu paket ke paket lain, dan dijalankan di sepanjang wilayah Kabupaten Barru, tempatnya dimulai dari bagian selatan ke ujung utara. Itulah secara beretika diberikan urutan-urutan karena mengingat salah satu streotipe sosial budaya di masyarakat; "Politi' ri Tanete, ja' ati sibawa sere'ati ri Berru, ajukajung sibawa kara-kara ri Soppeng Riaja,loppo sa'da sibawa borro' ri Mallusetasi “.39

Terhadap aspek-aspek adat atau Ade' di wilayah sepanjang Kabupaten Barru terdapat 4 (empat) bekas Swapraja atau Distrik dipimpin Kepala/Ketua.Semuanya menghadapi problema politik tradisional kecuali Kepala Swapraja Barru di Sumpang Minanga'E I Jonjong Kalimullahbergelar Karaeng Lembang Parang.40 Dari ketiga swapraja itu dianggapnya bermasalah politik, adalah bekas kerajaan-kerajaan tradisional sebagai diasumsikan secara klasik Kembar Tiga; salah satunya Swapraja bekas Kerajaan berdimensi otonom/tunggal Yaitu Swapraja/Distrik bekas Kerajaan Tanete, dan selainnya Swapraja bekas kerajaan-kerajaan berdimensi konfederasi atau Passiajingeng, yaitu Swapraja/Distrik Soppeng Riaja dan Mallusetasi, keduanya merupakan bekaskerajaan tradisional Lili'; Balusu, Nepo, Kiru-Kiru, Laboso/ Mangkoso, Siddo, Ajakkang, Batu-Pute, Bojo' dan sebagainya.

Oleh sebab itu, barangkali disebabkan salah satu kebencian berlebihan dari kelompok bangsawan melawan Belanda, yakni kelompok sebagai dipimpin seorang Raja di daerah misalnya Baso Balusu bergelar Sulle Datu'e di Soppeng Riaja,. Mereka pada bengis dan tidak sungkan-sungkannya mengucapkan laknat,

\footnotetext{
38 Artinya: Batu telah tenggelam, arti kiasan dari pada Datu atau Arung, naiklah pasir arti kiasan dari orang kebanyakan atau rakyat; Sebentar ada waktunya hanya sekali gerakan dari Datu/Arung, maka hilanglah rangkaian seluruh rakyat yang diibaratkan pasir, akan kembali kebawah $\mathrm{H}$. A. BatuEja bin A. Baso Tenrisessu, tinggal di Tompo' Penna Tanete, "Wawancara ", 2002.

${ }^{39}$ Artinya: Politik atau Kekuasaan di Tanete, Sakit hati dan iri di Barru, Pepohonan rindang dan perkara di Soppengriaja, Besar suara dan sombong di Mallusetasi.

${ }^{40}$ Iihat: Ibid. h. 106.
} 
Tanro Ade' peninggalannya, berkata:" Nigi-nigi tau range'ngi La Pute Mata mapparenta, pupuru'sorokawu'i matu paddimunrinna", (H.A.Munawar Bin A. Beddu, Pekerjaan Sekdes Balusu, tinggal di Lapasu, Maret 2007, Wawancara). ${ }^{41}$

Terdapat istilah tradisional " Mabusung ri Ade'E " 42, sekarang dari faktanya sekian lama telah banyak pelanggaran atau dosa tradisional dilakukan Para Penjabat Daerah, baik secara mandiri maupun secara consensus berkelompok, mereka saja sepakat dengan rakyat kebanyakan; misalnya memperjual-belikan tanah-tanah Arajang sebagai dianggap harta kehormatan tradisional yang menyebabkan semuanya pada habis dan musnah; gelar-gelar tradisional Datu, Petta,Bau',Andi, Daeng dan Puang seringkali diper-tentangkan di luar normanya, sementara gelar tradisional pada zaman dahulu sebagai disebutkan Uwa', tampaknya menghilang diperedaran sosial masyarakat sebagai seorang Pembesar bergelar La Battoa dan To Maraja. bahasa Bugis. Itulah halnya sebagai dahulu orang diberi kedudukan dan status tradisional Uwa', adalah kebanyakannya berbunyi; "Uwa'e situdangeng sibawa sianreang Datu'e; iyapa naengka Datu narekko' engka' Uwa'. Iyapa namatase' Datu'e, narekko' rijajian'toi pole' ri Uwa'e; Uwa'e ri Datu'e, menre'i yarega no'i ri Saoraja'e, engkai temmappesabbi; Pada isseng'i E Kalaki, narekko maraja' Uwa'i ri seddi'e Wanua-Kampong, ajeppu'i engkana Datu natampu' ri rilalen'na; makkeda'i Uwa'e: Sangadi engkaka' conga' ri langi'e naengka Puang'ku. ${ }^{43}$

Di Soppeng Riaja mengenai pemangkuan jabatan sebagaimana istilah Paku Alam/Mangku Bumi di daerah lain, yakni antara gelar tradisional Uwa' Kiru-Kiru sebagai Pemuka Adat' /To Riangkalanga'E Adanna bahasa Bugis artinya Pria Berwibawa, dan dengan gelar Arung Soppeng Riaja terdiri atas beberapa orang sekeluarga sebagai para mantan Kepala/Ketua Swapraja, sehingga salah seorang di antaranya digelar Petta Lawallu', dari padanya tergambar sekali berbeda mengenai kewibawaan di antara keduanya, sebagaimana terungkap dalam falsafah politik tradisional ; “Uwa' Kiru-Kiru, Petta Lawallu', matanre' mui pangka'na Uwa'E Kiru-

\footnotetext{
${ }^{41}$ Artinya: Barang siapa sebagai kawan Belanda memerintah, mereka akan terpuruk pula pada akhirnya.

${ }^{42}$ Artinya: Berbuat dosa terhadap adat atau budaya.

${ }^{43}$ Artinya: Predikat Uwa' dapat duduk dan makan bersama dengan predikat Datu.Itulah Datu ada karena terdapat Uwa'.Datu dapat semakin masak darahnya kalau dilahirkan juga dari predikat Uwa'.Mereka terhadap Datu, kalau saja meninggalkan Istana boleh tidak minta izin atau pamit.
} 
Berkiprah dengan Kelembagan Politik Tradisional di Kabupaten Barru SulawesiSelatan (Studi Sejarah dan Antropologi Politik)

Kiru. ${ }^{44}$ Itulah sistem politik tradisional/Lembaga Adat di Soppeng Riaja berada di bawah kepemilikan tradisional marga kumunitas Nene Gumali, baginya merupakan keluarga To Battoa/Pembesar Kiru-Kiru, dan secara politik tradisional bersejarah sebagai Pakkatenni Ade' /Paku Alam/Mangku Bumi bergelar"Uwa'Kiru-Kiru“.

Oleh sebab itu, segala peninggalan berbasis kolonial, misalnya saja $e x$ Arung/Kepala Swapraja Soppeng Riaja hendaknya diamandemen, sehingga setiap tanah dan di atasnya bangunan kepemilikannya, semuanya dapat dipertanyakan, atau setidaknya kembali diadakan revisi Mappasiruntu'E Laleng-Ada, Madeceng'E Ri Ola, Na Engkaki Salama Wali-wali, Degaga' Mappasalama Sangadina Polemua ri Puang,E Dewata Seuwa'E La Patoto To Palanro'E, Allahu Akbar. ${ }^{45}$ Demikianlah salah satu contohnya, reaksi gugatan tradisional dibalik pembentukan Lembaga Adat di Soppeng Riaja Kabupaten Barru.

Demikian tradisional menggunakan rumah panggung, melebihi aturannya dengan model Maega lontang'ni bolana, timpalaja'na massusungeng, ${ }^{46}$ juga mattuka' sapana toni dan dengannya mereka semaugue berlebihan jumlah anak tangganya. Dalam perkawinan, tatacaranya seperti aksesoris berlebihan Mallawa soji, berbusana pakaian tradisional songko' pamiring bersama dengan jas tutup; demikian pula tradisional memakai warna berpakaian baju bodo, dan sebagainya.

Itulah di atas gambarannya diambil sebagai contoh, di masyarakat, bahwa norma-norma budaya semakin amburadul.Sesungguhnya itu rasanya sangat ringan dikemukakan, karena pelanggarnya di mana-mana telah tak terhingga khususnya di Kabupaten Barru. Itulah halnya demi menyelamatkan budaya, maka masyarakat secara menyeluruh di Sulawesi-Selatan sebaiknya dituntut gerakan “ Mari kembali bertaubat kepada Adat ".

Oleh sebab itu, tentunya tidak kurang banyaknya kelompok bisa saja menyelemeh, bahwa kami sesungguhnya sudah kebanyakan melanggar adat, tentunya akan malu banget he he Istighfaar saja. Sehubungan dengan rasa malu sebagai disebutkan Siri ma raja', pada orang berkata, sebentar setelah tiba waktunya-

\footnotetext{
44 Artinya: Uwa' Kiru-Kiru dibanding dengan Petta Lawallu, maka predikat Uwa' Kiru-Kiru lebih tinggi pangkatnya dari pada predikat Petta Lawallu.

45 Artinya: Menpertemukan kata sepakatyang sebaiknya ditempuh, sehingga keduanya selamat, tidak ada yang memberi keselamatan kecuali Allah swt, Allah Maha Besar.

${ }^{46}$ Artinya: Rumahnya terdiri dari banyak petak, dan bubungannya bertingkat-tingkat.
} 
orang-orang pada malu, kecuali dua golongan sebagai disebutkan; "To makkatenni'e ri wajenpajeng, To maccinaung'e ri poccinagori; mattompo' ri tana maeso'e poada'i tongeng'e . ${ }^{47}$

Itu maksudnya hanya dua golongan yang tidak bakal malu; pertama, orangnya jujur konsisten tidak pernah statusnya berubah, tidak ke bawah dan tidak ke atas; kedua, orangnya tawaadhu' merendahkan diri', yaitu orang seharusnya dapat dibanggakan dan sombong, kedudukan dan statusnya di atas angin tetapi dirinya disembunyikan dan tidak angkuh. Oleh sebab itu, bagi orang bijakTo MaccaE/To PannawanawaE biasanya berkata; Iyatu tanra maraja, matase'e akkarungen'na tau subbu'eng'i alena, na mappakatuna ale', iyanatu mompo parimeng mancaji wijalawo". 48

Itulah di atas, sebagai faktanya diberikan gambaran adat di kemudian hari berkata; " Narekko' makkompe'ni Ade'e, masolannitu lipu'e, rilegga'ni welong panasa'e, massobuni tongeng'e, ripasalani tuju'e, ripattujuni sala'e, sianre' bale tau'e, sibalu'-balu', Siabbelling-belliang, natuwoini serri' dapureng'e, ri-paoppanni pallungeng'e, risappeang pattapi'e, riasseloreng, alu'e. 49

Sejalan dengan hal di atas,terdapat sumber lain berkata“ Seuwani Wettu ri Munri To Panrita'e Panrita bicaramani, taniana Panrita tongeng yarega hakiki, To Mapparenta'e padangkang toni; Iyana rekkoa'ero Golongeng maega doi'na, mappunnai tonangeng oto sibawa bola batu mattingka', Naiya ikkeng Pabbanua'emakkareso gangka ellong, De' gaga na lolongeng, Sangadinna perri' sibawa masemase, enreng'nge akasiasingEng." 50

Dengan demikian, untuk kembali kepada pembentukan Lembaga Adat sebagai suatu strategi nasional, adalah bukan sekadar kegiatan berisi asal-asalan,

\footnotetext{
47 H. Zainuddin, Pekerjaan Pemilik Hotel Gandaria Pare-Pare dan Budayawan, tinggal di Jl Bau Massepe, "Wawancara",tgl juni 2002.

${ }^{48}$ Artinya :Tanda bagi orang yang tinggi kebangsawanannya adalah bersikap menyembu-nyikan diri atau merendahkan diri.

${ }^{49}$ H. A. Mattulada, Op.Cit. h. 383. Artinya: Apabila Adat kendur, maka rusaklah negeri atau kampung. Tidak memetik pucuk nangka, bersembunyilah kebenaran.Dibenarkanlah yang salah dan disalahkanlah yang benar.Pada orang sudah seperti ikan memakan. Satu sama lain jual-menjual dan beli membeli. Dapur sudah ditumbuhi rumput-rumput, Lesung ditelungkupkan, Niru digantung, Antang atau Alu disangkutkan.

${ }^{50}$ Artinya;Ulama pada waktunya bukan lagi ulama hakiki melainkan sekedar Ulama Pidato, Pemerintah sebagai juga Pengusaha, Mereka pada berlomba memiliki mobil mewah dan rumah bertingkat, sementara rakyat yang bekerja keras sampai leher, tetap miskin dan melarat.
} 
melainkan sektornya beralasan sejarah dan regulasi. Selain pembentukannya berangkat dari pasal 32 UUD’ 45, juga sesudahnya beberapa kebijakan setelah zaman reformasi, sebagai berikut:

1. Undang-Undang RI No. 5 Tahun 1992 Tentang Benda Cagar Budaya.

2. TAP/MPR No. IV/MPR/1999 Tentang GBHN 1999-2004 Tentang Arah kebijakan di bidang sosial budaya, aspek kebudayaan, “ Mengembangkan dan membina Kebudayaan Nasional Bangsa Indonesia yang bersumber dari warisan leluhur Bangsa, Budaya Nasional yang mengandung nilai-nilai universal, termasuk kepercayaan terhadap Tuhan Yang Maha Esa dalam rangka mendukung ter-peliharanya kerukunan hidup bermasyarakat dan membangun Peradaban Bangsa “.

3. GBHPD Sulawesi-Selatan Tahun 2000-2004: Bab IV. Strategi dan Kebijakan di bidang budaya lokal sebagai berikut:

a. Menjadikan nilai-nilai Budaya Lokal yang dianut dan dikembangkan oleh masyarakat bersangkutan sebagai patokan dalam bertingkah laku dan digunakan untuk mengukur keberhasilan pembangunan.

b. Memelihara, meningkatkan dan mengembangkan Budaya Lokal yang bersumber dari nilai-nilai tradisional untuk membentuk, memperkuat jati diri Bangsa, mendukung berkembangnya kemandirian sosial.

c. Memelihara dan memanfaatkan situs sejarah dan budaya lokal untuk mendukung pembangunan Daerah.

4. Surat Gubernur Sulawesi-Selatan No. 430/1462/SET Tanggal 23 April 2003, Perihal Pembentukan Lembaga Adat Daerah dengan maksud agar para Bupati/ Walikota bersama-sama dengan elemen masyarakat di daerahnya untuk menggali dan melestarikan kebudayaan serta kearifan lokal yang dimiliki dengan memfasiltasi pembentukan Lembaga Adat/Pemangku Adat atau sejenisnya sesuai khasanah budaya lokal masing-masing dengan tetap berpegangan pada aturan perundang-undangan.

Menurut Saing, bahwa tehnis pembentukan Lembaga Adat, diambil setelah menjadi kesepakatan masyarakat setempat, kemudian dituangkan dalam satu peraturan daerah yang mengatur secara formal keberadaan 
lembaga budaya yang dimaksud. ${ }^{51}$ Peraturan Daerah Kabupaten/Kota tentang pembentukan Lembaga Adat sedapat mungkin dirampungkan secepatnya

Pertanyaan selanjutnya dapat dikemukakan, apa dan sejauhmana kearifan Bupati Barru dapat memberi tanggung-jawab demi tegaknya Lembaga Adat Kabupaten Barru. Dari pertanyaan itu bukan dimaksudkan menagih dan menggugah, tetapi dengannya dapat dinilai akan seperti apa mereka di Kabupaten Barru dibalik pembentukan Lembaga Adat ?

Untuk mendukung hal-hal yang berkaitan dengan pembentukan Lembaga Adat ditugaskan kepada Kepala Dinas Kebudayaan dan Pariwisata Provinsi Sulawesi-Selatan beserta Tim Ahli dari Para Pakar dan Budayawan agar turut membantu Kabupaten yang memerlukan penjelasan, sehingga dapat terwujud dengan baik .52

5. Surat Deputi Menteri Kebudayaan dan Pariwisata Bidang Nilai Budaya, seni dan film tanggal 28 Mei 2003 No. Ot. 001/2/21 D. NBSF. KKP. 03. Perihal tanggapan atas pembentukan Lembaga Adat Daerah. Dalam hal ini, Menteri me-rekomendir adanya kegiatan pembentukan Lembaga Adat SulawesiSelatan sebagai upaya pengembangan dan kelestariannya kebudayaan nasional.

6. Pemerintah Daerah Provinsi Sulawesi-Selatan memfasilitasi Penyelenggara-an Seminar Pembentukan Lembaga Adat Daerah Sulawesi-Selatan yang diselenggarakan di Makassar pada tanggal 06 Desember 2003, dihadiri oleh Budaya-wan, Pemangku Adat dan sebagainya. Seminar tersebut dibuka secara resmi oleh Gubernur Sulawesi-Selatan Bapak H.M. Amin Syam.

7. Surat Gubernur Sulawesi-Selatan No. 430/043/SET/ tgl 05 Januari 2004 Perihal Lembaga Adat Daerah/Pemangku Adat. Dari intinya menghimbau kepada Para Bupati/Walikota se Sulawesi-Selatan untuk menindak lanjuti rumusan dan Seminar Pembentukan Lembaga Adat Daerah Sulawesi-Selatan.

8. Rumusan sebagai Rekomendasi Seminar Pembentukan Lembaga Adat Sulawesi-Selatan tgl. 06 Desember 2003 di Makassar, adalah hasil rumusan ditandatangani oleh para peserta sebanyak 37 orang, antara lain utusan dari

\footnotetext{
51 Asma Saing, Op. Cit. h.03.

52 Lihat: Ibid.
} 
Kabupaten Bone dihadiri oleh Bapak. Drs.Andi Baso Hamid dan Drs. Andi Yusran.

\section{Kesimpulan}

Ikhtisar sebagai akhir uraian, bahwa perspektif membangun Lembaga Adat di Kabupaten Barru, bagi penulis adalah pekerjaan yang sedianya sangat melelahkan dan meresahkan.Tidakkah di sepanjang wilayah Kabupaten Barru kebanyakannya dicaplok oleh kolonialisme dan peninggalannya di mana-mana, sehingga semuanya secara arif-bijaksana terlebih dahulu hendaknya diluruskan atau diamandemen. Dengan demikian, konfigurasi tradisional atau Adat dapat dinyatakan dengan gamblang telah keluar dari belenggunya penjajahan setelah waktu satu abad (1908-2008)

Bukankah berdasarkan kondisional secara historis Kabupaten Barru tidak sama dengan status dan situs di daerah lain yang bergelar Bocco' dalam bahasa Bugis artinya induk atau pusat misalnya Bone, Wajo, Soppeng, Luwu dan Gowa.Oleh sebab itu, berdasarkan legitimasi dan otoritas ilmu pengetahuan dan aplikasinya, terdapat teori sejarah dan antropologi, mempertanyakan kelembagaan kolonial yang kini masih berpengaruh di atas kelembagan tradisional atau adat di Kabupaten Barru. Itu terjadi pada tiga kecamatan sebagai bekas Swapraja atau Distrik, yaitu, Soppeng Riaja-Mangkoso, Mallusetasi-Palanro, dan Tanete-Barru

Semua sebagai disebutkan, disimpulkan para Penutur Lontara di Kabupaten Barru, berkata; “Engka'i tania sijajian lino' (tana'e); engka'i tania riaseng pammulang yarega ade'; engka'i tania ritella'e ammemengeng sibawa tongeng ". 53

\footnotetext{
${ }^{53}$ Artinya: Mereka ada bukan karena dilahirkan di atas bumi pertiwi sebagaI milik moyang sendiri, berarti mereka dinilai berada di luar ahliwaris atau pendatang. Mereka bukan permulaan atau disebut sesungguhan tradisional.
} 


\section{Daftar Pustaka}

A. Rahman Rahim, Nilai-Nilai Utama Orang Bugis, (Ujungpandang: Lembaga Penerbitan UNHAS, 1985).

A.J. Wensinck, Concodance Et Indices De La Tradision Muslimane, (Leiden E.J Brill, 1936)

Ahmad Fedyani Saifuddin, Antropologi Kontemporer, Suatu Pengantar Kritis Paradigma, (Rawamangun Jakarta: Kencana Prenada Media Group, 2006)

Amri Marzali, Antropologi \& Pembangunan Indonesia, (Jakarta: Kencana Indonesia, 2007)

Asma Saing: “ Kebijakan Pembentukan Lembaga Adat/Pemangku Adat “, Makalah (2007)

H. Zainuddin, Pekerjaan Pemilik Hotel Gandaria Pare-Pare dan Budayawan, tinggal di Jl Bau Massepe, "Wawancara ",tgl juni 2002.

Jamali, Abdoel Rauf, Pengantar Hukum Indonesia, (Jakarta: PT. Grafindo Persada, 1999)

M. Dien Majid \& Johan Wahyudi, Ilmu Sejarah Sebuah Pengantar, (Jakarta: Kencana Prenada Media Group, 2016). Cet. I

Mattulada, Latoa, Suatu Analisis Terhadap Antropologi Politik Orang Bugis, (Ujungpandang: Hasanuddin University Press)

Muhibbin AM, Staf Peneliti FKIY Yogyakarta, " Seputar Indonesia " Berita Harian ", Resensi Buku, Menyelami Pemikiran Tokoh dalam resensi buku Marnie Hughes-Warrinton " 50 Tokoh Penting Dalam Sejarah ", terbit Minggu, 6 April 2008.

Stoddard, L., Dunia Baru Islam, ( Jakarta: Panitia, 1966)

Sunarmi, Sejarah Hukum, (Rawamangun Jakarta: Kencana Prenada Media Group, 2016) Cet. I, 